\title{
STRUCTURAL EVOLUTION OF A SEGMENTED NORMAL FAULT TRANSFER ZONE, SEVIER FAULT, SOUTHERN UTAH
}

BENJAMIN SURPLESS, Trinity University

\section{INTRODUCTION}

While it has long been recognized that major normal fault systems are commonly segmented in map view, as opposed to continuous, planar surfaces (e.g., Goguel, 1952; Tchalenko, 1970; Wallace, 1970; Schwartz and Coppersmith, 1984), only recently have researchers made significant advances in the role that segmentation plays in the evolution of these fault systems (e.g., Biddle and Christie-Blick, 1985; Crone and Haller, 1991; Peacock and Sanderson, 1996; Peacock, 2002). The geometry and relative strength of links between fault segments can strongly influence the propagation of slip during an earthquake (e.g., King and Nabalek, 1985; Crone and Haller, 1991; Zhang et al., 1991), and the perturbations of the local stress field caused by interaction of fault segments can influence the formation of relay ramps, minor faults, and associated fracture networks in transfer zones between synthetic normal fault segments (e.g., Peacock and Sanderson, 1996; Crider and Pollard, 1998; Faulds and Varga, 1998; Peacock, 2002).

In addition, the high fracture densities developed at these segment boundaries (e.g., Stock and Hodges, 1990; Hudson, 1992; Faulds, 1996) may enhance fluid flow, thus increasing rates of groundwater flow (e.g., Rowley, 1998), permitting hydrocarbon migration (e.g., Morley et al., 1990), and promoting more effective ore mineralization (e.g., DeWitt et al., 1986). Because normal faults that typically develop in sedimentary basins, where natural resources commonly occur, are relatively planar and steeplydipping in cross-section, with displacements of up to hundreds of meters (e.g., Peacock, 2002), wellexposed fault systems with these characteristics permit researchers to shed light on the evolution of similar faults in the subsurface. In this Keck Utah Advanced Project, students used the Sevier fault zone in southern Utah (Fig. 1), a segmented normal fault system with $\sim 600-700 \mathrm{~m}$ dip-slip displacement, to investigate the structural evolution of a normal fault transfer zone across a range of spatial scales.

\section{STUDY AREA}

The Sevier normal fault, considered one of the most important structures in the Basin and Range province (e.g., Davis, 1999; Lund et al., 2008), is part of the Toroweap-Sevier fault system, which extends for more than $300 \mathrm{~km}$ from northern Arizona to southern Utah (Fig. 1). The fault has accommodated extension across the transition zone from the Basin and Range province to the relatively stable Colorado Plateau since the Miocene (e.g., Reber et al., 2001; Lund et al., 2008), and previous workers have noted the potential of the fault to produce significant earthquakes (Anderson and Rowley, 1987; Doelling and Davis, 1989; Anderson and Christenson, 1989; Lund et al., 2008). It is likely that many segments of the Sevier fault reactivate older high-angle, Laramide-age contractional structures (e.g., Stewart and Taylor, 1996; Schiefelbein and Taylor, 2000), which may explain why the steeply-west-dipping fault zone is segmented in map view, with variations in the geometry of the linkages between normal fault segments (e.g., Davis, 1999; Reber et al., 2001; Schiefelbein, 2002; Doelling, 2008).

In this project, students focused their investigations on a particularly complex portion of the Sevier fault zone, termed the Orderville geometric bend (e.g., Reber et al., 2001) (Fig. 2). The Orderville bend displays a range of geometries associated with the interactions of three fault segments, which include, 
from south to north, the Mt. Carmel segment, the Highway 89 segment, and the Spencer Bench segment. The interaction of these 3 fault segments is likely responsible for the formation of the minor faults (displayed in white) and relay ramps shown adjacent to Red Hollow Canyon and Stewart Canyon (Fig. 2); these features likely evolved within the perturbed stress field associated with the transfer zones between dominant fault segments (Fig. 3).

\section{STUDENT PROJECTS}

The excellent vertical and lateral exposure of the Jurassic Navajo sandstone at the two primary study areas, at Red Hollow Canyon and Elkheart Cliffs (Fig. 2), provided students opportunity to directly observe faults, fractures, and deformation bands within these well-studied lithologies (e.g., Rogers et al., 2004; Schultz et al., 2010; Solom et al., 2010). The Elkheart Cliffs exposure (Fig. 2) displays the simplest fault geometry because the Mt. Carmel segment accommodates all E-W extension. In contrast, at Red Hollow Canyon, extensional strain is accommodated by a more complex system that includes the Orderville relay ramp and several other faults (Fig. 2 ). This spatial variation in fault complexity allows student researchers to treat these two locations as end members, permitting them to evaluate how the evolution of different fault geometries damages adjacent rock volumes (Fig. 3).

To address fundamental questions about how rock volumes respond to the evolution of complex, segmented, normal fault systems, students applied a wide variety of approaches, including analysis of field data, 3D digital modeling of photographic data, ArcGIS analysis of major fracture sets, and geomechanical modeling of fault propagation through well-bedded sandstone layers. Their work improves our understanding of the 3D evolution of fracture networks in complex normal fault zones, which has important implications for natural resource exploration.

Charley Hankla (College of Wooster) interpreted field-based fracture data in the context of fault-zone evolution. He used fracture data from 8 different scanlines, which permit documentation of fracture intensity and orientation along a horizontal line, as measured perpendicular to the dominant strike of the fracture set. To analyze the data, Charley plotted all fractures on stereonets and calculated basic statistics for each fracture population (e.g., average strike value). He then used these fracture orientation data in combination with precise, GPS-located map data and compressive strength data to relate fracturing to a newly-mapped fault segment within in the Red Hollow Canyon, named the Lion's Den fault (Fig. 2).

Charley clearly demonstrates that most fractures formed subparallel to the dominant fault segments in the area, with strikes of approximate $030^{\circ}$, supporting his hypothesis that the fault segments and fractures propagated within the same stress field, likely at the same time. Additionally, he notes the likelihood that fractures formed in the tip damage zone ahead of the propagating Lion's Den fault (Fig. 3C), reducing the cohesion of the rock and permitting northward propagation of the segment. Charley points out that fractures at significantly different orientations are consistent with joints documented in Zion National Park, to the east, where researchers suggest formation in a rotated regional stress field.

Caroline McKeighan (Trinity University) used a combination of field data and photographic data collected by unmanned aerial vehicle (UAV) to analyze variability in lateral and vertical fracture patterns. She compares fractures documented at the more complex Red Hollow Canyon (RHC) transfer zone (Fig. 2) to those from the Elkheart Cliffs locality, where all strain is accommodated by a single fault segment (Mt. Carmel segment, Fig. 2). As part of her project, she developed a new modeling protocol to efficiently document inaccessible fractures using Agisoft Photoscan Professional. Using a combination of these 3D digital outcrop models and field data, Caroline found that fracture intensities adjacent to the Mt. Carmel segment were significantly higher than from any location across the RHC transfer zone, where fractures were more broadly distributed. However, fracture intensity decreased rapidly with increasing distance from the Mt. Carmel segment, nearly disappearing when more than 100 meters from the fault contact, while fracture intensities remained relatively constant across the entire RHC transfer 


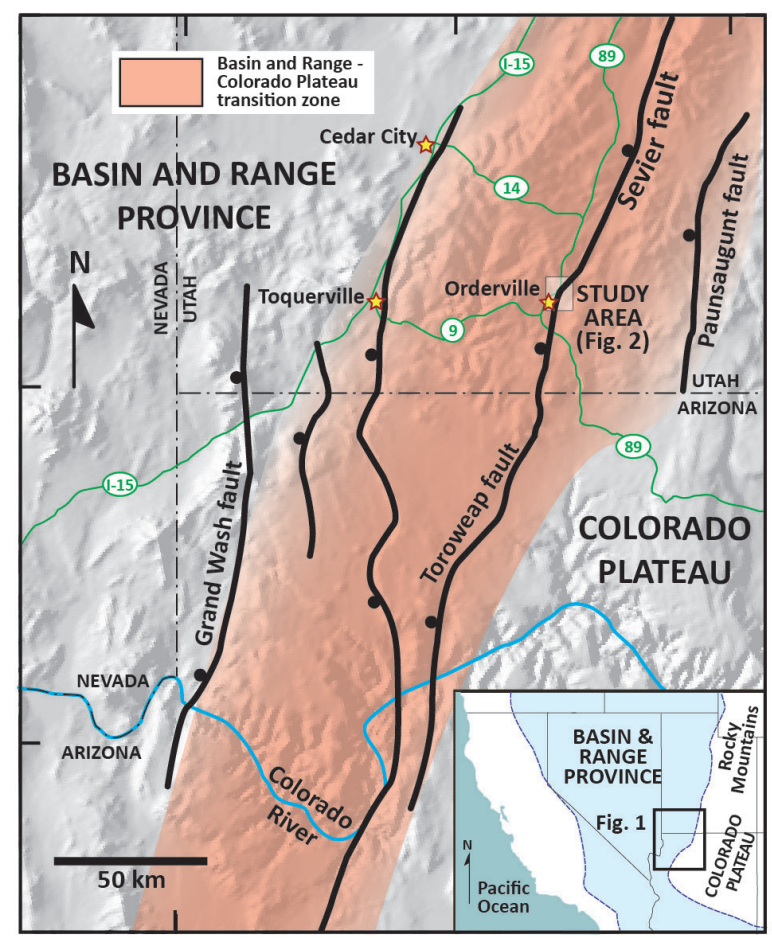

Figure 1. Physiographic context for the Sevier fault zone study area within the Basin and Range-Colorado Plateau transition zone (see inset). In combination with the Grand Wash, Hurricane, and Paunaugunt faults, the Sevier-Toroweap fault helps accommodate extension across the transition zone. Ball is on the hanging wall of the west-dipping faults. Detailed geology of the Sevier fault study area (boxed) is displayed in Figure 2. Digital shaded relief modified from Thelin and Pike (1991). Figure significantly modified from Reber et al. (2001).

zone. In addition, she found that fracture intensities changed abruptly within the vertical stratigraphy, and zones of higher fracture intensity at one level rarely correlated with higher fracture intensities above or below.

These results suggest that fluid flow within fracture networks would likely be higher adjacent to a single fault segment but limited in lateral extent, while in a transfer zone, flow rates would be lower but with a broader distribution of flow. Vertical fracture data suggest that vertical fluid flow would be much more difficult to predict.

Curtis Segarra (Trinity University) utilized geomechanical finite-element modeling software, ABAQUS/CAE (by Dessault Systemes), to analyze the spatial distribution of stress and strain fields within well-layered sandstone bedding ahead of a propagating fault tip. The modeling software permitted Curtis to control a range of important physical variables, including bed thickness, elastic moduli of fault blocks and bedding, friction between sedimentary rock layers, and fault geometry and displacement. He systematically tested for the displacement required to achieve initial plastic failure within modeled layers as well as for the displacement required to achieve throughgoing plastic failure through the layered stack. His results suggest that the initial stages of fault propagation within a layered system are characterized by complex patterns of stress and strain accumulation, with bedding contacts perturbing the stress field. Although somewhat predictable, the initial locations of high stress and strain are not along the projection of the fault, where expected, but are instead located meters off-plane, along bed contacts. However, by the

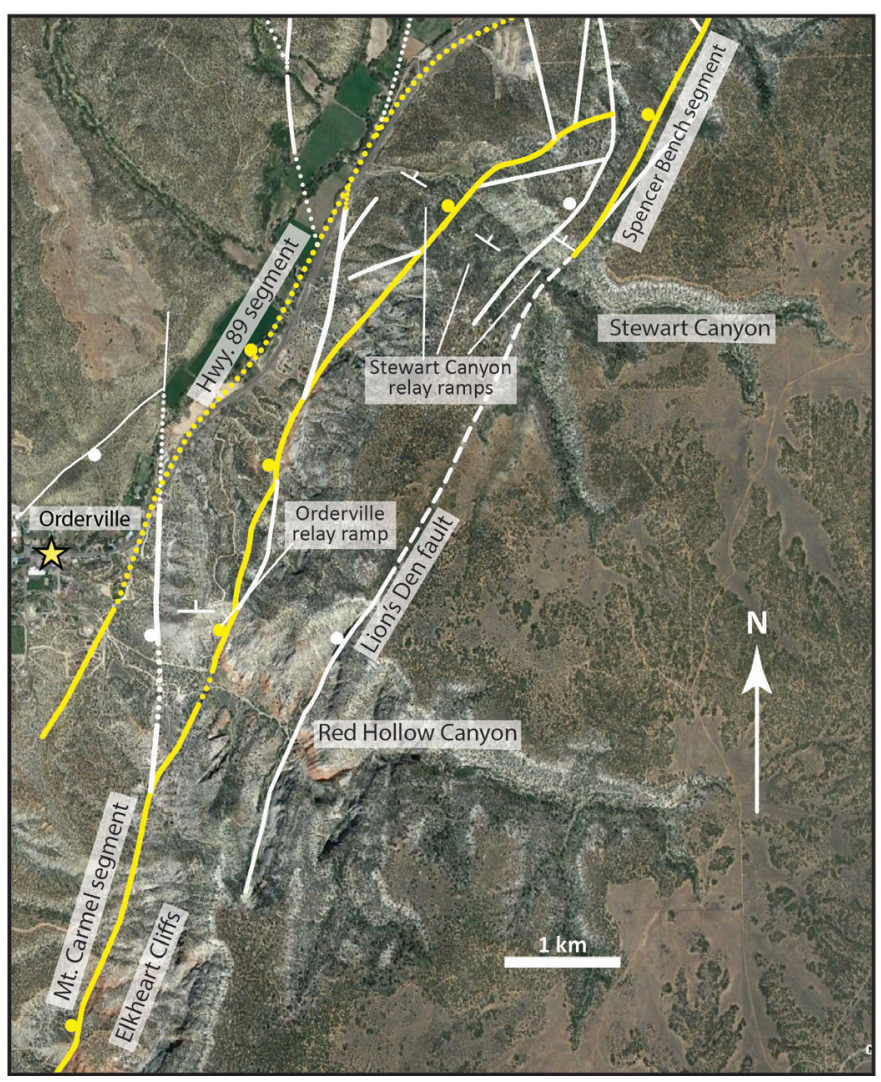

Figure 2. Fault map of the Sevier fault zone near Orderville, Utah. Yellow lines indicate normal faults that accommodate significant $(>100 \mathrm{~m})$ displacement or play an important role in fault linkage, and white lines indicate normal faults that play a role in strain accommodation but display lesser displacements. Ball symbols are on the hanging wall. Study locations include the Red Hollow Canyon transfer zone and the Elkheart Cliffs area, adjacent to the Mt. Carmel fault segment. Labels identify relay ramps within transfer zones. Faults and relay ramps shown here are based primarily on Schiefelbein (2002) and on the results of research completed as part of this Keck Advanced Project. See Figure 1 for location. 

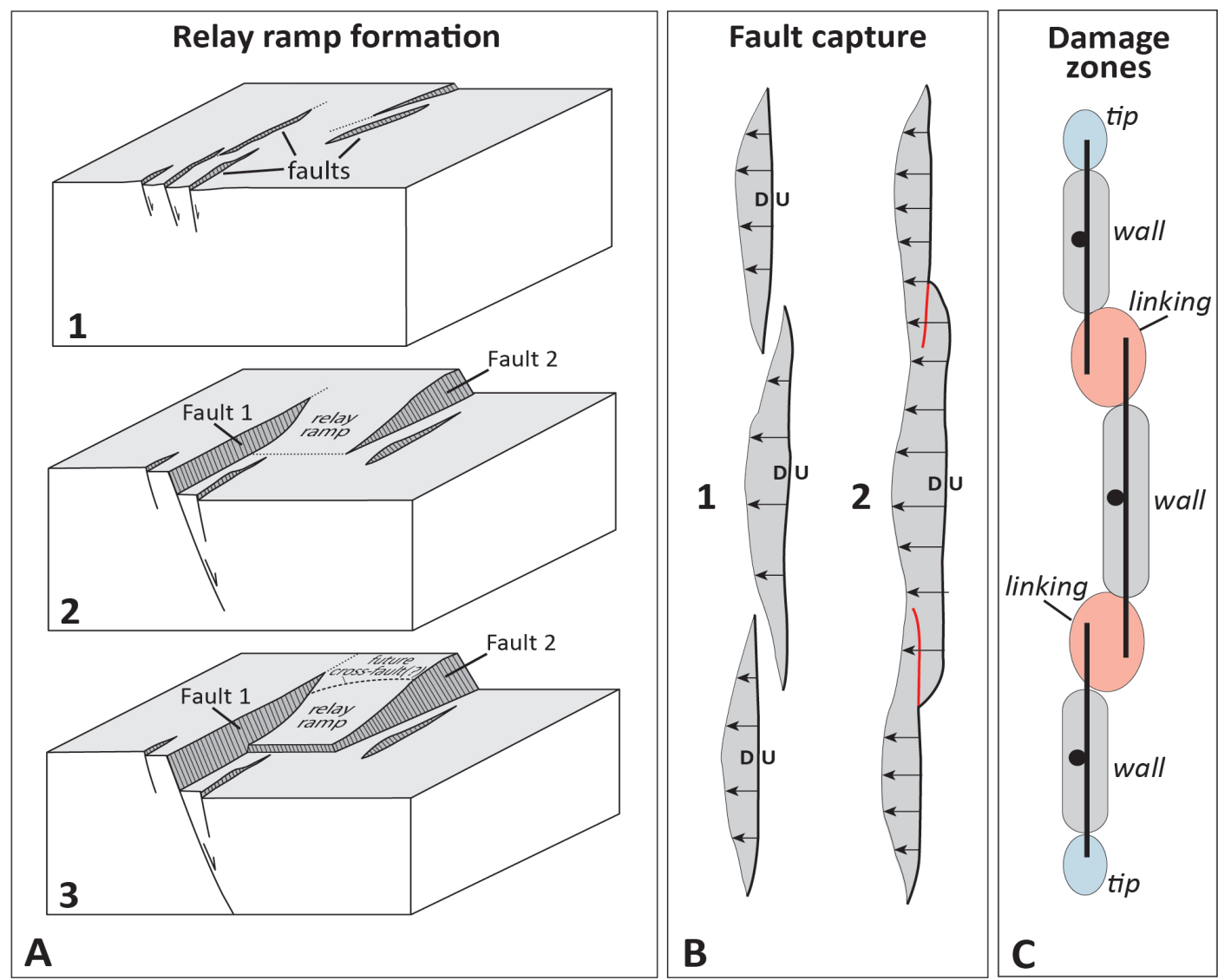

Figure 3. Diagrams displaying relay ramp development, fault capture, and damage zone classification. A) In all diagrams, the dark gray shaded area represents the magnitude of displacement, and the lines represent the slip direction as the hanging wall drops relative to the footwall. 1. A system of small-displacement faults develops to accommodate upper crustal stresses. The dotted lines represent the future propagation of the faults. 2. As displacement increases across the system, two faults (1 and 2) become dominant, both lengthening in map view and displaying increasing total displacement. A relay ramp forms in the zone of overlap between the faults. 3. Faults 1 and 2 link as a new cross-fault connects them. A future cross-fault may form where indicated, fully breaching the relay ramp. B) Map-view of a segmented fault system (bold lines are faults), with 1 and 2 representing progressive stages of fault segment linkage and capture. In 1, the three fault segments overlap but are only soft linked, and in 2, one of the segments has "captured" displacement from the other segments, isolating the overlapped portions of segments (red lines) that are no longer active. The segments are now hard linked and act as a single, corrugated fault. Arrows show the direction and relative magnitude of fault slip projected onto plan view. C) Schematic map view diagram of damage zone types associated with a segmented normal fault system (bold lines) with ball symbols on the hanging wall. Figure A. adapted from Peacock (2002) and Long and Imber (2011), Figure B. adapted from Reber et al. (2001), and Figure C. adapted from Kim et al. (2004).

time through-going failure occurs, these zones of strain accumulation (i.e., fractures) coalesce into a more coherent zone parallel to and in-plane with the propagating fault.

His research has significant implications for how tip damage zones evolve during fault propagation, which we can use to better understand results from fieldbased fracture studies like those undertaken by other students on this Keck Utah Project. More broadly, we can apply his results to the propagation of any fault through sedimentary layering, especially in the subsurface, where fracture networks cannot be directly observed.

Madison Woodley (Mt. Holyoke College) focused on a detailed ArcGIS-based analysis of fracture networks, comparing data from the Red Hollow Canyon transfer zone to data from the Elkheart Cliffs, where a single fault segment accommodates all strain. She used a wide range of data, including orthorectified photography, digital elevation models, and high-resolution Google Earth imagery to build a detailed base map. Madison then added previous geologic mapping (Schiefelbein, 2002), so that she could use both rock unit distributions and faults 
to provide context for her fracture analysis. She then built a fracture dataset as a layer in ArcMap, marking fractures and using ArcGIS tools to provide orientation data for each marked fracture. Finally, she used another tool to measure spacing between each fracture along well-defined scanlines, allowing her to assess both fracture intensity and relative clustering of fractures (clustering is quantified by the coefficient of variation, $\mathrm{Cv}$; see Woodley, this volume, for a detailed explanation).

Madison's data clearly show that the different fault zone geometries affect the orientations of fractures, fracture intensity, and relative clustering. At the Red Hollow Canyon transfer zone, her data suggest that more strain is accommodated over a larger area than at the Elkheart Cliffs locality, with greater clustering than at Elkheart Cliffs. She also points out that one fracture orientation dominates strain accommodation in the Elkheart Cliffs, while multiple fracture sets are present across the transfer zone. Madison proposes a model where the stress field within the rocks adjacent to the single fault segment locality was constant over time, while the presence of multiple faults linked across the transfer zone produce a more complex fracture network.

\section{ACKNOWLEDGEMENTS}

This material is based upon work supported by the Keck Geology Consortium and the National Science Foundation under Grant No. 1659322. Fieldwork was also supported by the Trinity University Department of Geosciences, and our time on Trinity University's campus was supported by the Trinity University Summer Undergraduate Research Program. Dr. Kevin Smart, at Southwest Research Institute, provided excellent guidance to Curtis Segarra, permitting Curtis to perform detailed and accurate geomechanical analysis.

\section{REFERENCES}

Anderson, R.E., and Christenson, G.E., 1989, Quaternary faults, folds, and selected volcanic features in the Cedar City $1^{\circ} \times 2^{\circ}$ quadrangle, Utah: Utah Geological and Mineral Survey Miscellaneous Publication 89-6, 29 p.
Anderson, J.J., and Rowley, P.D., 1987, Geologic map of the Panguitch NW quadrangle, Iron and Garfield Counties, Utah: Utah Geological and Mineral Survey Map 103, 8 p. pamphlet, scale $1: 24,000$.

Biddle, K.T., and Christie-Blick, N., 1985, Strike - slip deformation, basin formation, and sedimentation, In: Biddle, K.T., Christie-Blick, N., Eds.: Strike- Slip Deformation, Basin Formation, and Sedimentation. Society of Economic Mineralogists Special Publication, v. 37 , p. $375-386$.

Crider, J., and Pollard, D., 1998, Fault linkage: Threedimensional mechanical interaction between echelon normal faults: Journal of Geophysical Research, v. 103 , p. 24,373-24,391.

Crone, A.J., and Haller, K.M., 1991, Segmentation and the coseismic behavior of Basin and Range normal faults: examples from east-central Idaho and southwest Montana, U.S.A.: Journal of Structural Geology, v. 13, p. 151- 164.

Davis, G., 1999, Structural geology of the Colorado Plateau region of southern Utah, with special emphasis on deformation bands: Geological Society of America Special Paper 342.

DeWitt, E., Thompson, J., and Smith, R., 1986, Geology and gold deposits of the Oatman district, northwestern Arizona: U.S. Geologic Survey Open-File Report 86-0638, 34 p.

Doelling, H.H., 2008, Geologic map of the Kanab 30’x60' quadrangle, Kane and Washington Counties, Utah, and Coconino and Mohave Counties, Arizona, 1:100,000-scale: Utah Geological Survey, MP-08-2DM.

Doelling, H.H., and Davis, F.D., 1989, The geology of Kane County, Utah, with sections on petroleum and carbon dioxide by Cynthia J. Brandt: Utah Geological and Mineral Survey Bulletin 124, 192 p., scale 1:100,000, 10 plates.

Faulds, J., 1996, Geologic map of the Fire Mountain 7.5' quadrangle, Clark County, Nevada, and 
Mohave County, Arizona: Nevada Bureau of Mines and Geology Map 106, scale 1:24,000 (with accompanying text).

Faulds, J., and Varga, R., 1998, The role of accommodation zones and transfer zones in the regional segmentation of extended terranes, In Faulds, J.E., and Stewart, J.H., Eds., Accommodation zones and transfer zones: the regional segmentation of the Basin and Range province: Geological Society of America Special Paper No. 343, p. 1 - 45.

Goguel, J., 1952, Traite de Tectonique: Masson, Paris (Translated by Thalmann, H.E., 1962). Tectonics: Freeman Publishing Company, San Francisco, $384 \mathrm{p}$.

Hudson, M., 1992, Paleomagnetic data bearing on the origin of arcuate structures in the French Peak - Massachusetts Mountain area of southern Nevada: Geological Society of America Bulletin, v. 104 , p. $581-594$.

Kim, K.-S., Peacock, D., and Sanderson, D., 2004, Fault damage zones: Journal of Structural Geology, v. 26, p. 503-517.

King, G.C.P., and Nabalek, J.L., 1985, The role of bends in faults in the initiation and termination of earthquake rupture: Science, v. 228, p. $984-$ 987.

Long, J., and Imber, J., 2011, Geological controls on fault relay zone scaling: Journal of Structural Geology, v. 33, p. $1790-1800$.

Lund, W.R., Knudsen, T.R., and Vice, G.S., 2008, Paleoseismic reconnaissance of the Sevier fault, Kane and Garfield Counties, Utah: Utah Geologic Survey Special Study 122, Paleoseismology of Utah, v. 16, 31 p.Lowe, D., 2004, Distinctive image features from scale invariant keypoints: International Journal of Computer Vision, v. 60, p. 91-110, doi: 10.1023 /B: VISI .0000029664 .99615.94.

Morley, C., Nelson, R., Patton, T., and Munn, S., 1990, Transfer zones in the East African Rift system and their relevance to hydrocarbon exploration in rifts: American Association of Petroleum Geologists Bulletin, v. 74, p. $1234-1253$.

Peacock, D.C.P., 2002, Propagation, interaction and linkage in normal fault systems: Earth-Science Reviews, v. 58, p. $121-142$.

Peacock, D.C.P., and Sanderson, D.J., 1996, Effects of propagation rate on displacement variations along faults: Journal of Structural Geology, v. 18, p. $311-320$.

Reber, S., Taylor, W., Stewart, M., and Schiefelbein, I., 2001, Linkage and Reactivation along the northern Hurricane and Sevier faults, southwestern Utah, In M.C. Erskine, J.E. Faulds, J.M. Bartley, P.D. Rowley, Eds., The Geologic Transition, High Plateaus to Great Basin - A Symposium and Field Guide, The Mackin Volume: Utah Geological Association Publication 30, Pacific Section American Association of Petroleum Geologists Publication GB78, p. 379 - 400 .

Rogers, C., Myers, D., and Engelder, T., 2004, Kinematic implications of joint zones and isolated joints in the Navajo Sandstone at Zion National Park, Utah: Evidence for Cordilleran relaxation: Tectonics, v. 23, TC1007, doi:10.1029/2001TC001329.

Rowley, P., 1998, Cenozoic transverse zones and igneous belts in the Great Basin, Western United States: Their tectonic and economic implications In Faulds, J.E., and Stewart, J.H., Eds., Accommodation zones and transfer zones: the regional segmentation of the Basin and Range province: Geological Society of America Special Paper No. 343, p. 195-228.

Schiefelbein, I., 2002, Fault segmentation, fault linkage, and hazards along the Sevier fault, southwestern Utah [M.S. thesis]: Las Vegas, University of Nevada at Las Vegas, 132 p. 
Schiefelbein, I., and Taylor, W., 2000, Fault development in the Utah transition zone and High Plateaus subprovince: Abstracts with Programs, v. 32 , No. 7, p. 431.

Schultz, R., Okubo, C., and Fossen, H., 2010, Porosity and grain size controls on compaction band formation in Jurassic Navajo Sandstone: Geophysical Research Letters, v. 37, L22306, , doi:10.1029/2010GL044909.

Schwartz, D.P., and Coppersmith, K.J., 1984, Fault behavior and characteristic earthquakes Examples from the Wasatch and San Andreas fault zones: Journal of Geophysical Research, v. 89 , p. $5681-5698$.

Solum, J., Brandenburg, J., Kostenko, O., Wilkins, S. and Schultz, R., 2010, Characterization of deformation bands associated with normal and reverse stress states in the Navajo Sandstone, Utah: AAPG Bull., v. 94, p. 1453-1475, doi:10.1306/01051009137.

Stewart, M., and Taylor, W., 1996, Structural analysis and fault segment boundary identification along the Hurricane fault in southwestern Utah: Journal of Structural Geology, v. 18, p. 1017 1029.

Stock, J., and Hodges, K., 1990, Miocene to recent structural development of an extensional accommodation zone, northeastern Baja California, Mexico: Journal of Structural Geology, v. 12, p. $312-328$.

Tchalenko, J.S., 1970, Similarities between shear zones of different magnitudes: Bulletin of the Geological Society of America, v. 81, p. 16251640.

Thelin, G.P., and Pike, R.J., 1991, Landforms of the Conterminous United States - A Digital Shaded-Relief Portrayal: U.S.G.S. Geologic Investigations Series I - 2720.
Wallace, R.E., 1970, Earthquake recurrence intervals on the San Andreas fault: Bulletin of the Seismological Society of America, v. 81, p. 2875 -2890 .

Zhang, P., Slemmons, D.B., and Mao, F., 1991, Geometric pattern, rupture termination and fault segmentation of the Dixie Valley- Pleasant Valley active normal fault system, Nevada, U.S.A.: Journal of Structural Geology, v. 13, p. 165-176. 